\title{
The complete larval development of Armases benedicti (Rathbun) (Decapoda, Sesarmidae), from the Amazon region, reared in the laboratory
}

\author{
Jô de F. Lima \& Fernando Abrunhosa
}

Núcleo de Estudos Costeiros, Universidade Federal do Pará. Campus de Bragança, Alameda Leandro Ribeiro, Aldeia, 68600-000 Bragança, Pará, Brasil.E-mail: jodeflima@yahoo.com.br; faraujo@ufpa.br

\begin{abstract}
The four zoeal and one megalopal stages of the wharf crab Armases benedicti (Rathbun, 1897) larvae reared in the laboratory are described and illustrated in detail. The mean duration for each larval stage was 3 , $2,4,4$ and 13 days, respectively. The duration of the larval period from hatching to the first juvenile was 26 days. Morphologically, $A$. benedicti is very similar to the reported species of genus. However, a small lateral spine is clearly observed in the carapace of zoeal stages of this species. This feature appears to be unique among the family Sesarmidae. Another distinctive character for this species is the zoeal setation of the maxilla endopod $(2+2)$ in which most of the sesarmids have setation $(2+3)$ except for Sesarma tetragonum (Fabricius, 1798). Other comparisons with previous larval studies of the genus Armases Abele, 1992 are briefly discussed.
\end{abstract}

KEY WORDS. Caeté estuary; larval morphology; sesarmid.

\begin{abstract}
RESUMO. O desenvolvimento larval completo de Armases benedicti (Rathbun) (Decapoda, Sesarmidae), da região Amazônica, obtido em laboratório. São descritos e ilustrados em detalhes, os quatro estágios de zoea e um de megalopa do caranguejo Armases benedicti (Rathbun, 1897), a partir de larvas obtidas em laboratório. A média de duração de cada estágio larval foi 3, 2, 4, 4 e 13 dias, respectivamente. O período compreendido desde a eclosão até o surgimento do primeiro juvenil foi de 26 dias. Morfologicamente $A$. benedicti é muito similar às outras espécies do gênero, contudo, um pequeno espinho lateral é claramente observado na carapaça das zoeas desta espécie. Esta característica aparenta ser única dentre os Sesarmidae. Outra característica distinta desta espécie é a distribuição das cerdas do endópodo da maxila $(2+2)$, o qual difere dos demais sesarmídeos que apresentam a distribuição $(2+3)$, exceto para Sesarma tetragonum (Fabricius, 1798) o qual apresenta $(2+2)$. Outras comparações morfológicas com trabalhos anteriores relacionados a larvas do gênero Armases Abele, 1992 são brevemente discutidas.
\end{abstract}

PALAVRAS-CHAVE. Estuário do Caeté; morfologia larval; sesarmídeo.

The morphological descriptions of larvae are considered valuable in the elaboration key in the classification of the planktonic species and for phylogenetic studies, making explanation possible about evolutionary strategies for decapods. The culture of larvae in laboratory has, undoubtedly, contributed significantly to obtaining such knowledge (Rice 1980, MARQUES \& Pohle 1996a, b, Pereyra Lago 1987, 1989, 1993). However, despite of the many studies available on reared larvae, many species still remain unknown (ANGER 1995).

The family Sesarmidae, proposed by MARTIN \& DAVIS (2001), has 37 recorded species in which the larval development is studied (IsLAm et al. 2002). However, some species continue with their larval stage unknown. According to IsLAm et al. (2002), the literature has reported an extensive and useful list on larval development, in which five species are present belonging to the genus Armases: A. cinereum (Bosc, 1802) by Costlow \& Bоокноuт (1960);
A. ricordi (H. Milne Edwards, 1853) and A. rubripes (Rathbun, 1897) both by Diaz \& EWALD (1968), A. angustipes (Dana, 1852) by CUESTA \& ANGER (2001) and A. miersii (Rathbun, 1897) by CUESTA et al. (1999), where their complete larval development is described from larvae reared in the laboratory.

Four species of Armases Abele, 1992 are recorded as being inhabited in Brazil: A. rubripes, A. ricordi, A. angustipes and A. benedicti (Rodriguez 1980, Melo 1996). The later is a common crab occurring in oligohaline water, living on deed woods and stone in the margin of oligohaline streams on the northeastern coast of the state of Pará and Amapá and it is the only species in which the larval development is still not reported.

The present study provides a detailed description and illustration of zoeal and megalopal stages of $A$. benedicti. A brief comparative study with other species of the genus Armases is also provided.

Revista Brasileira de Zoologia 23 (2): 460-470, junho 2006 


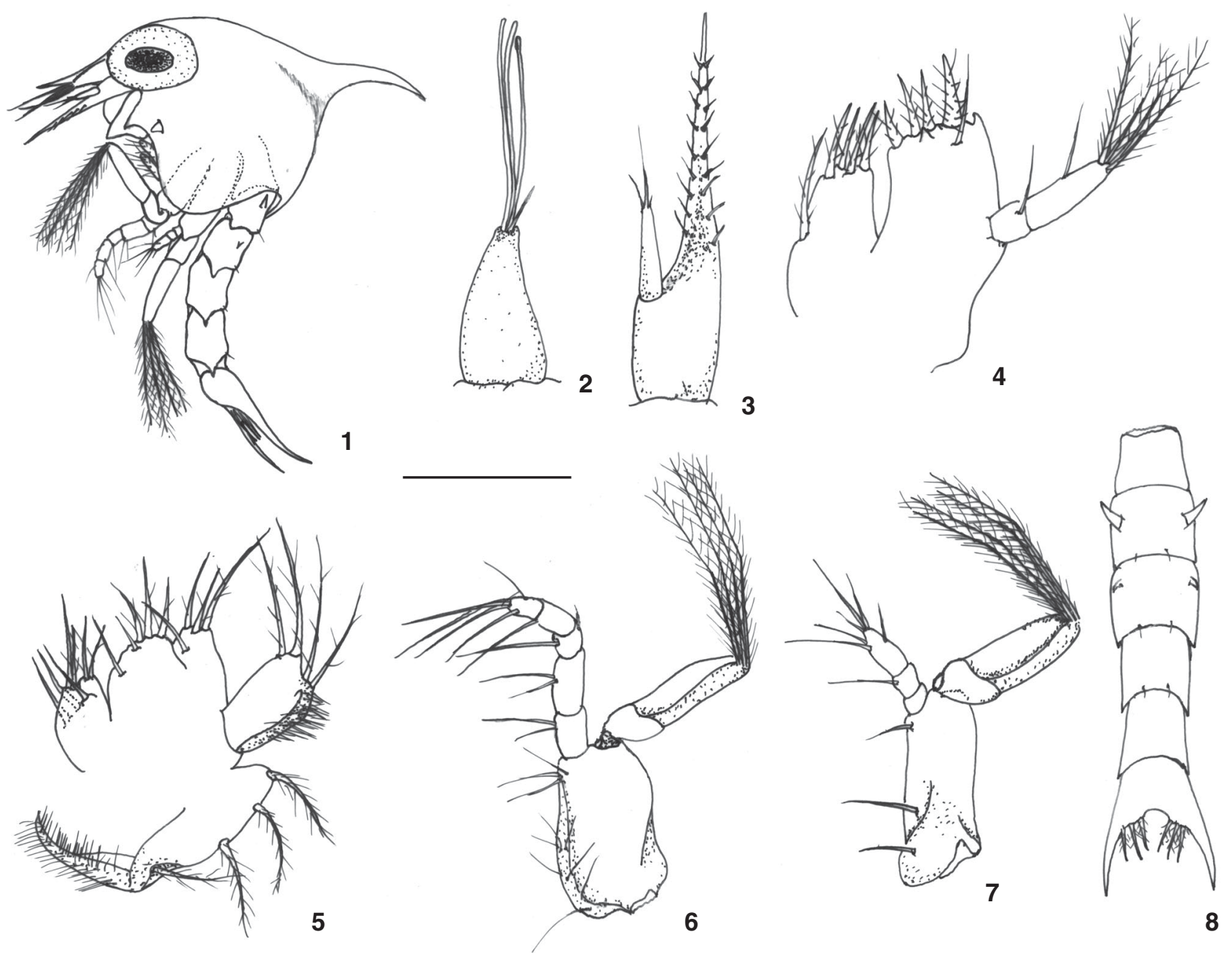

Figures 1-8. Armases benedicti: (1) zoea I, lateral view; (2) antennule; (3) antenna; (4) maxillule; (5) maxilla; (6) first maxilliped; (7) second maxilliped; (8) abdomen and telson. Scale bar: $1=0.3 \mathrm{~mm}, 2-5=0.075 \mathrm{~mm}, 6-7=0.15 \mathrm{~mm}, 8=0.24 \mathrm{~mm}$.

\section{MATERIAL AND METHODS}

Three ovigerous females of Armases benedicti were manually collected along the margin of the River Caeté estuary, Bragança City, Pará, and carried to the laboratory. They were carefully washed and conditioned in aquariums (capacity $5 \mathrm{l}$ ). Immediately after the hatching, around 600 larvae (200/female) were transferred into three recipients $(500 \mathrm{ml}$ ) filled with $400 \mathrm{ml}$ of filtered water with constant aeration. The water was monitored daily and salinity of $15 \mathrm{ppt}$, pH 8.2 and temperature of $27^{\circ} \mathrm{C}( \pm 1.5)$ were maintained constant. The larvae were fed with newly hatched nauplii of Artemia Leach, 1819. Microalgae Thalassiosira Cleve, 1873 was added to the culture recipients to maintain of the water quality. The numbers of larval stages, survival rate and the intermolting period were monitored carefully during cultivation.

Samples of each larval stage and exuviae were preserved in alcohol 70\%+ glycerol (1:1) solution. The samples were dissected using fine needles under an ocular microscope Zeiss Axioskop 40 equipped with an ocular micrometer disc. The carapace length was measured from ocular region to posterior margin of the carapace. At least, 10 larvae and postlarvae were used for illustration and measurements.

The terminology used in the morphological descriptions follows Díaz \& Ewald (1968), Bousquette (1980), Pereyra Lago (1987,1989, 1993), Marques \& Pohle $(1996 a, b)$, Magalhães \& Medeiros (1998), Cuesta \& Anger (2001), Islam et al. (2002, 2004), Guerao et al. (2004) and Abrunhosa et al. (2005).

\section{RESULTS}

The larval development of $A$. benedicti consists of four zoeae and one megalopa. Intense feeding activity and cannibalistic behavior were observed during the zoeal and megalopal 
stages. The mean duration for each larval stage was 3, 2, 4, 4 for zoeae and 13 days for megalopa, respectively. The duration of larval period from hatching to first juvenile was 26 days (Tab. I). Appendages and setation evolution of Armases benedicti during the zoeal development are shown in the table II. Morphological comparisons among previously described for genus Armases (zoea I and megalopa stages) and present study are shown in the tables III, IV, and V, respectively.

\section{Zoea I}

Carapace length: $0.26 \mathrm{~mm}(0.25-0.28 \mathrm{~mm})$.

Carapace (Fig. 1): globose and smooth bearing with one dorsal, one rostral and two lateral spines. Dorsal spine curved downward. Rostral spine straight. Lateral spine small, approximately perpendicular to the carapace measuring about $1 / 4$ of the dorsal spine. Posterior and ventral margins lacking setae. Eyes sessile.
Antennule (Fig. 2): uniramous unsegmented, conical. Exopod with three long aesthetascs and one simple terminal seta.

Antenna (Fig. 3): well-developed, approximately twice the rostral spine length. Protopod a little longer than rostral spine,

Table I. Survival rate, intermolting period and accumulative days for Armases benedicti reared in the laboratory.

\begin{tabular}{lccc}
\hline Larval stage & $\begin{array}{c}\text { Intermolting } \\
\text { period }\end{array}$ & $\begin{array}{c}\text { Accumulative } \\
\text { days }\end{array}$ & $\begin{array}{c}\text { Survival rate } \\
(\%)\end{array}$ \\
\hline Zoea I & 3 & 3 & 100 \\
Zoea II & 2 & 5 & 98 \\
Zoea III & 4 & 9 & 34 \\
Zoea IV & 4 & 13 & 12 \\
Megalopa & 13 & 26 & 2 \\
Juvenile & $*$ & $*$ & 1 \\
\hline
\end{tabular}

*) Not recorded.

Table II. Appendages and setation evolution of Armases benedicti during the zoeal development. (S) Setation, (A) aesthetascs, (Seg) segment, (Ep) epipod, (Prot.) protopod, (Ex) exopod, (BE) basal endite, (CE) coxal endite, (End) endopod, (Scap) scaphognathite.

\begin{tabular}{|c|c|c|c|c|}
\hline Appendages & Zoea I & Zoea II & Zoea III & Zoea IV \\
\hline \multicolumn{5}{|l|}{ Antennule } \\
\hline$A+S$ & $3+1$ & $4+1$ & $4+1$ & $5+1$ \\
\hline \multicolumn{5}{|l|}{ Antenna } \\
\hline End & absent & small bud & small bud & 2- segmented \\
\hline \multicolumn{5}{|l|}{ Maxillule } \\
\hline Prot - S & absent & 1 & 2 & 1 \\
\hline End - Seg & 2 & 2 & 2 & 2 \\
\hline End - $S$ & 1 and $4+1$ & 1 and $4+1$ & 1 and $4+1$ & 1 and $4+1$ \\
\hline$C E-S$ & $4+1$ & $5+1$ & $5+1$ & $5+1$ \\
\hline$B E-S$ & $4+1$ & $4+3$ & $5+3$ & $8+3$ \\
\hline \multicolumn{5}{|l|}{ Maxilla } \\
\hline End - Seg & 1 & 1 & 1 & 1 \\
\hline End - $S$ & $2+2$ & $2+2$ & $2+2$ & $2+2$ \\
\hline$C E-S$ & $3+4$ & $4+4$ & $5+3$ & $6+3$ \\
\hline$B E-S$ & $4+5$ & $4+5$ & $4+5$ & $5+6$ \\
\hline Scap - S & 4 & $5+3$ & 13 & 22 \\
\hline \multicolumn{5}{|l|}{ Maxilliped I } \\
\hline Exop - Seg & 2 & 2 & 2 & 2 \\
\hline Ex $-S$ & 4 & 6 & 8 & 10 \\
\hline Seg - End & 5 & 5 & 5 & 5 \\
\hline End - $S$ & $2,2,2,1$ e 5 & $2,2,2,1$ e 5 & $2,2,2,1$ e 5 & $2,2,2,2$ e 5 \\
\hline \multicolumn{5}{|l|}{ Maxilliped II } \\
\hline Seg - Exop & 2 & 2 & 2 & 2 \\
\hline Exop - S & 4 & 6 & 8 & 10 \\
\hline Seg - End & 3 & 3 & 3 & 3 \\
\hline End - $S$ & $0,1,6$ & $0,1,6$ & $0,1,5$ & $0,1,6$ \\
\hline Maxilliped III & minute bud & small bud & endopod e exopod differentiated & End. e Ex. completely differentiated \\
\hline Pereiopods & minute bud & minute bud & Segmented & cheliped chelated \\
\hline Pleopods & absent & absent & minute bud & endopod bud present \\
\hline Abdomen & 5 somites & 5 somites & 6 somites & 6 somites \\
\hline
\end{tabular}


Table III. Morphological comparisons among previously described for Armases zoea I and present study. Data were obtained from previous descriptions, illustrations, and present study. (S) Setation, (A) aesthetascs, (Ba) basipod, (Seg) segment, (Ex) exopod, (BE) basal endite, (CE) coxal endite, (End) endopod, (Scap) scaphognathite, (Sp) spines, (nd) no data.

\begin{tabular}{|c|c|c|c|c|c|c|}
\hline Appendages & A. rubripes (1) & A. ricordi (2) & A. miersii (3) & A. cinereum (4) & A. angustipes (1) & A. benedicti (5) \\
\hline Carapace & present & present & absent & absent & absent & present \\
\hline Lateral - Sp & as a small protuberance & as a small protuberance & & & & as a small spine \\
\hline Antennule - S & $3 \mathrm{~A}, 1 \mathrm{~S}$ & $3 \mathrm{~A}, 2 \mathrm{~S}$ & $3 \mathrm{~A}, 2 \mathrm{~S}$ & $3 \mathrm{~A}, 2 \mathrm{~S}$ & $3 \mathrm{~A}, 2 \mathrm{~S}$ & $3 \mathrm{~A}, 1 \mathrm{~S}$ \\
\hline \multicolumn{7}{|l|}{ Antenna } \\
\hline Prot - Sp & 1 rows & 2 rows & 2 rows & 1 rows & 2 rows & 2 rows \\
\hline$E X-S, S p$ & 2,1 & 2,2 & 2,0 & 2,0 & 2,2 & 2,1 \\
\hline \multicolumn{7}{|l|}{ Maxillule } \\
\hline End - $S$ & $1,4+1$ & $1,4+1$ & $1,4+1$ & $1,4+1$ & $1,4+1$ & $1,4+1$ \\
\hline$C E-S$ & 5 & 5 & 6 & 5 & 6 & $4+1$ \\
\hline$B E-S$ & 5 & 5 & 5 & 5 & 5 & $4+1$ \\
\hline \multicolumn{7}{|l|}{ Maxilla } \\
\hline End - $S$ & $2+3$ & $2+3$ & $2+3$ & $2+3$ & $2+3$ & $2+2$ \\
\hline$C E-S$ & 8 & 8 & 8 & 7 & 8 & 7 \\
\hline$B E-S$ & 9 & 9 & 9 & 9 & 9 & 9 \\
\hline Scap - S & 4 & 4 & 4 & 4 & 4 & 4 \\
\hline \multicolumn{7}{|l|}{ Maxilliped I } \\
\hline $\mathrm{Ba}$ & $2,2,3,3$ & $2,2,3,3$ & $2,2,3,3$ & nd & $2,2,3,3$ & $2,2,3,3$ \\
\hline$E x-S$ & 4 & 4 & 4 & 4 & 4 & 4 \\
\hline End - $S$ & $2,2,1,2,5$ & $2,2,1,2,5$ & $2,2,1,2,5$ & $1,1,1,2,4$ & $2,2,1,2,5$ & $2,2,2,1,5$ \\
\hline \multicolumn{7}{|l|}{ Maxilliped II } \\
\hline Exop - $S$ & 4 & 4 & 4 & 4 & 4 & 4 \\
\hline End - $S$ & $0,1,6$ & $0,1,6$ & $0,1,6$ & $0,1,6$ & $0,1,6$ & $0,1,6$ \\
\hline
\end{tabular}

1) Cuesta \& Anger (2001), 2) Díaz \&Ewald (1968), 3) Cuesta et al. (1999), 4) Costlow \& Bookhout (1960), 5) Present work.

Table IV. Summarize of the main morphological characters of megalopa of Sesarmidae, which occur in the Brazilian mangroves.

\begin{tabular}{llccccc}
\hline \multicolumn{1}{c}{ Species } & \multicolumn{1}{c}{ Font } & $\begin{array}{c}\text { Antenna } \\
\text { segmentation }\end{array}$ & $\begin{array}{c}\text { Maxillule } \\
\text { endopod setae }\end{array}$ & $\begin{array}{c}\text { Scaphognathite } \\
\text { marginal setae }\end{array}$ & $\begin{array}{c}\text { First maxilliped } \\
\text { exopod setae }\end{array}$ & $\begin{array}{c}\text { Pleopods } \\
\text { exopod setae }\end{array}$ \\
\hline Sesarma rectum & Fransozo \& HEBLING (1986) & 9 & 1,5 (2-segmented) & $33-36$ & 2,6 & $13,13,13,11,6$ \\
S. curacaoense & ANGER et al. (1995) & 9 & 1,5 (2-segmented) & 22 & 3,5 & $12,12,12,9,6$ \\
Aratus pisonii & WARNER (1968) & 9 & 1,5 (2-segmented) & 30 & no data & $13,13,13,10,7$ \\
Armases rubripes & DíAz \& EWALD (1968) & 9 & 1,5 (2-segmented) & \pm 40 & 3,4 & $13,13,13,11,6$ \\
A. angustipes & CUESTA \& ANGER (2001) & 9 & 2,4 (2-segmented) & 39 & 3,4 & $13,16,17,15,7$ \\
A. ricordi & DíAz \& EWALD (1968) & 9 & 2,4 (2-segmented) & 50 & 3,4 & $13,13,13,11,8$ \\
A. benedicti & Present study & 9 & 6 (unsegmented) & $30-31$ & 3,3 & $14,13,13,11,6$ \\
\hline
\end{tabular}

bearing two rows of small spines. Endopod absent. Exopod with two terminal setae and one small spine.

Maxillule (Fig. 4): endopod 2-segmented, proximal segment with one simple seta and distal segment with one simple setae and four long terminal setae. Basal endite with four plumodenticulate and one simple setae. Coxal endite with $4+$ 1 plumodenticulate setae. Protopod absent.

Maxilla (Fig. 5): scaphognathite with four plumose setae and one elongate distal process with microtrichia as illustrated. Endopod unsegmented with $2+2$ long plumose setae showing marginal microtrichia. Basal endite with proximal and distal lobes almost fused with $5+4$ setae. Coxal endite with proximal and distal lobes fused with $4+3$ setae.

First Maxilliped (Fig. 6): basipod with internal margin bearing 2,2,3,3 simple setae. Endopod 5-segmented with 2,2,2,1,4+1 setae, respectively. Exopod 2-segmented, proximal 
Table V. Morphological comparison between previously described for Armases megalopa and the present study. Data were obtained from previous descriptions, illustrations, and the present study. (S) Setation, (A) aesthetascs, (Ba) basipod, (Seg) segment, (Ex) exopod, (BE) basal endite, (CE) coxal endite, (End) endopod, (Scap) scaphognathite, (Sp) spines, (nd) no data.

\begin{tabular}{|c|c|c|c|c|c|c|}
\hline Appendages & A. rubripes (1) & A. ricordi (2) & A. miersii (3) & A. cinereum (4) & A. angustipes (1) & A. benedicti (5) \\
\hline \multicolumn{7}{|l|}{ Antennule } \\
\hline Peduncle - S & $3,1,3$ & $3,1,1$ & $5,1,1$ & $3,1,1$ & $4,1,1$ & $0,1,1$ \\
\hline Flagelum - A & $0,7,5$ & $0,9,5$ & $0,7,6$ & $0,6,5$ & $0,8,5$ & $0,5,4$ \\
\hline \multicolumn{7}{|l|}{ Antenna } \\
\hline Peduncle - S & $2,1,1$ & $1,1,1$ & $2,1,1$ & $0,0,1$ & $0,1,1$ & $0,1,1$ \\
\hline Flagelum - S & $0,2,1,4,1,3$ & $0,2,1,5,1,3$ & $0,2,2,5,1,3$ & $0,2,1,2,1,2$ & $0,2,1,5,1,3$ & $0,2,0,3,0,3$ \\
\hline \multicolumn{7}{|l|}{ Maxillule } \\
\hline End - $S$ & 2,4 & 2,4 & 2,4 & 2,4 & 3,4 & 6 \\
\hline$C E-S$ & 11 & 11 & 12 & 9 & 11 & 11 \\
\hline$B E-S$ & 17 & 18 & 20 & 12 & 15 & $14-16$ \\
\hline \multicolumn{7}{|l|}{ Maxilla } \\
\hline End - $S$ & 0 & 0 & 1 & 2,3 & 1,3 & 0 \\
\hline$C E-S$ & 14 & 14 & 15 & 13 & 16 & 14 \\
\hline$B E-S$ & 12 & 12 & 16 & 14 & 15 & 13 \\
\hline Scap - S & $35+5$ & $45+5$ & $33+3$ & $30+0$ & $39+3$ & $35+2$ \\
\hline \multicolumn{7}{|l|}{ Maxilliped I } \\
\hline End - $S$ & 2 & 2 & 2 & 8 & 4 & 2 \\
\hline$E x-S$ & 3,4 & 3,4 & 2,3 & 3,5 & 3,4 & 3,3 \\
\hline \multicolumn{7}{|l|}{ Maxilliped II } \\
\hline End - $S$ & $0,1,3,6$ & $0,1,3,6$ & $0,1,4,7$ & $0,1,6,6$ & $0,1,4,8$ & $0,1,3,6$ \\
\hline$E x-S$ & 1,5 & 1,5 & 1,5 & 0,5 & 1,6 & 1,5 \\
\hline \multicolumn{7}{|l|}{ Maxilliped III } \\
\hline End - $S$ & $8,9,3,4,7$ & $8,9,4,3,6$ & $10,9,4,4,7$ & $7,6,3,2,5$ & $10,8,3,4,6$ & $7,8,4,4,3$ \\
\hline$E x-S$ & 1,5 & 1,4 & 1,5 & 0,5 & 1,4 & 0,5 \\
\hline
\end{tabular}

1) Cuesta \& Anger (2001), 2) Díaz \&Ewald (1968), 3) Cuesta et al. (1999), 4) Costlow \& Bookhout (1960), 5) Present work.

segment short, distal segment with four plumo-natatory setae.

Second Maxilliped (Fig. 7): basipod with three simple setae. Endopod 3-segmented with 0,1,(5+1) setae, respectively. Exopod 2-segmented, proximal segment short, distal segment with four plumo-natatory setae.

Abdomen (Fig. 8): Five abdominal somites; somites 2 and 3 with a pair of acute dorsolateral spines projecting anteriorly in somite 2. Pleopods absent.

Telson (Fig. 8): articulate with five abdominal somites and bifurcated posteriorly. Posterior margin with six $(3+3)$ setae. Two rows of teeth in inner part of each furcal branch.

\section{Zoea II}

Carapace length: $0.33 \mathrm{~mm}(0.32-0.34 \mathrm{~mm})$.

Carapace (Fig. 9): similar to previous stage. Eyes stalked. Antennule (Fig. 10): exopod with four long aesthetascs and 1 simple terminal seta.

Antenna (Fig. 11): protopod reaching rostral spine.

Maxillule (Fig. 12): basal endite with $4+3$ plumodenti- culate setae. Protopod present.

Maxilla (Fig. 13): scaphognathite with $5+3$ setae. Coxal endite with proximal and distal lobes partially fused with $4+4$ setae.

First Maxilliped (Fig. 14): exopod with distal segment bearing six plumo-natatory setae. Endopod with $2,2,1,2,4+1$ simple setae.

Second Maxilliped (Fig. 15): exopod with distal segment bearing six plumo-natatory setae.

Abdomen (Figs 9-16): similar to previous stage.

Telson (Fig. 16): similar to previous stage.

\section{Zoea III}

Carapace length: $0.52 \mathrm{~mm}(0.51-0.53 \mathrm{~mm})$.

Carapace (Fig. 17): similar to previous stage. Eyes stalked. Antennule (Fig. 18): similar to previous stage.

Antenna (Fig. 19): protopod as illustrated. Endopod bud a little longer than exopod. Exopod similar to previous stage. Maxillule (Fig. 20): basal endite with six plumodenticulate 


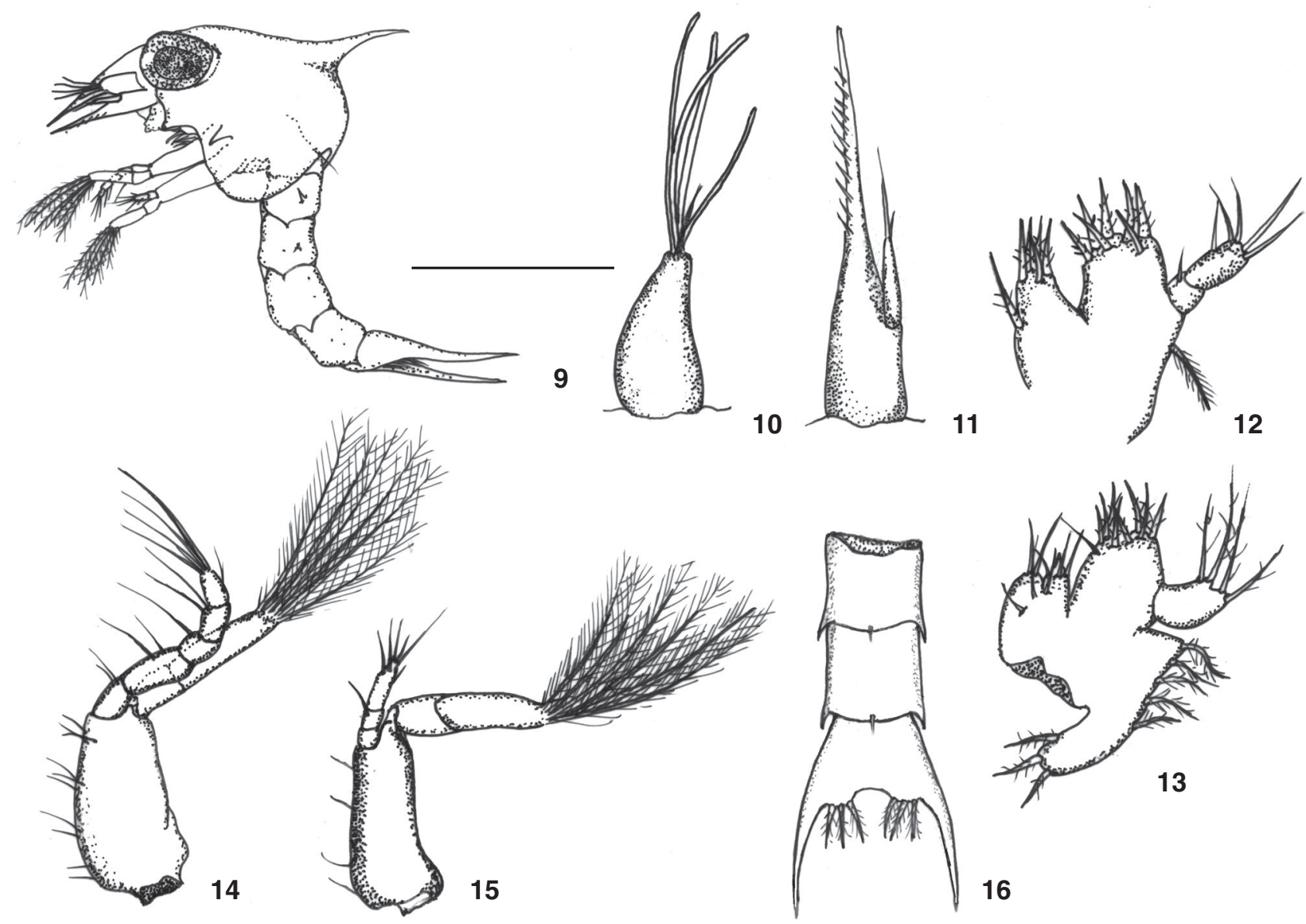

Figures 9-16. Armases benedicti: (9) zoea II, lateral right view; (10) antennule; (11) antenna; (12) maxillule; (13) maxilla; (14) first maxilliped; (15) second maxilliped; (16) abdomen and telson. Scale bar: $9=0.52 \mathrm{~mm}, 10=0.14 \mathrm{~mm}, 11=0.15 \mathrm{~mm}, 12-13=0.16 \mathrm{~mm}$, $14-15=0.26 \mathrm{~mm}, 16=0.33 \mathrm{~mm}$.

and $(1+1)$ simple setae. Coxal endite with $(5+1)$ and 1 simple seta. Protopod present with two long plumose setae.

Maxilla (Fig. 21): scaphognathite with 13 marginal setae. Basal endite with proximal and distal lobes with four plumodenticulate and five simple setae, respectively. Coxal endite with eight setae and one short spine, as illustrated.

First maxilliped (Fig. 22): exopod with eight plumo-natatory setae.

Second maxilliped (Fig. 23): exopod with eight plumonatatory setae.

Abdomen (Figs 17-24): showing six abdominal somites.

Pleopods (Fig. 17): buds, present on the second to sixth abdominal somites.

Pereiopods (Fig. 17): present, rudimentary.

\section{Zoea IV}

Telson (Fig. 24): similar to previous stage.

Carapace length: $0.62 \mathrm{~mm}(0.60-0.65 \mathrm{~mm})$.

Carapace (Fig. 25): similar to previous stage. Eyes stalked.
Antennule (Fig. 26): exopod with five long terminal aesthetascs and one simple seta.

Antenna (Fig. 27): protopod almost twice endopod length. Endopod 2-segmented surpassing the tip of distal seta of the exopod.

Maxillule (Fig. 28): basal endite with 9-10 terminal plumodenticulate and one simple basal seta. Protopod with one plumose setae.

Maxilla (Fig. 29): scaphognathite with 20-22 plumose setae. Basal endite with $5+6$ setae. Coxal endite with nine setae and one short spine in the distal lobe.

First maxilliped (Fig. 30): exopod with 10 plumo-natatory setae.

Second maxilliped (Fig. 31): exopod with 10 plumo-natatory setae.

Third maxilliped (Fig. 32): bud. Endopod and exopod visible.

Pereiopods (Fig. 25): segmented bud as illustrated. 

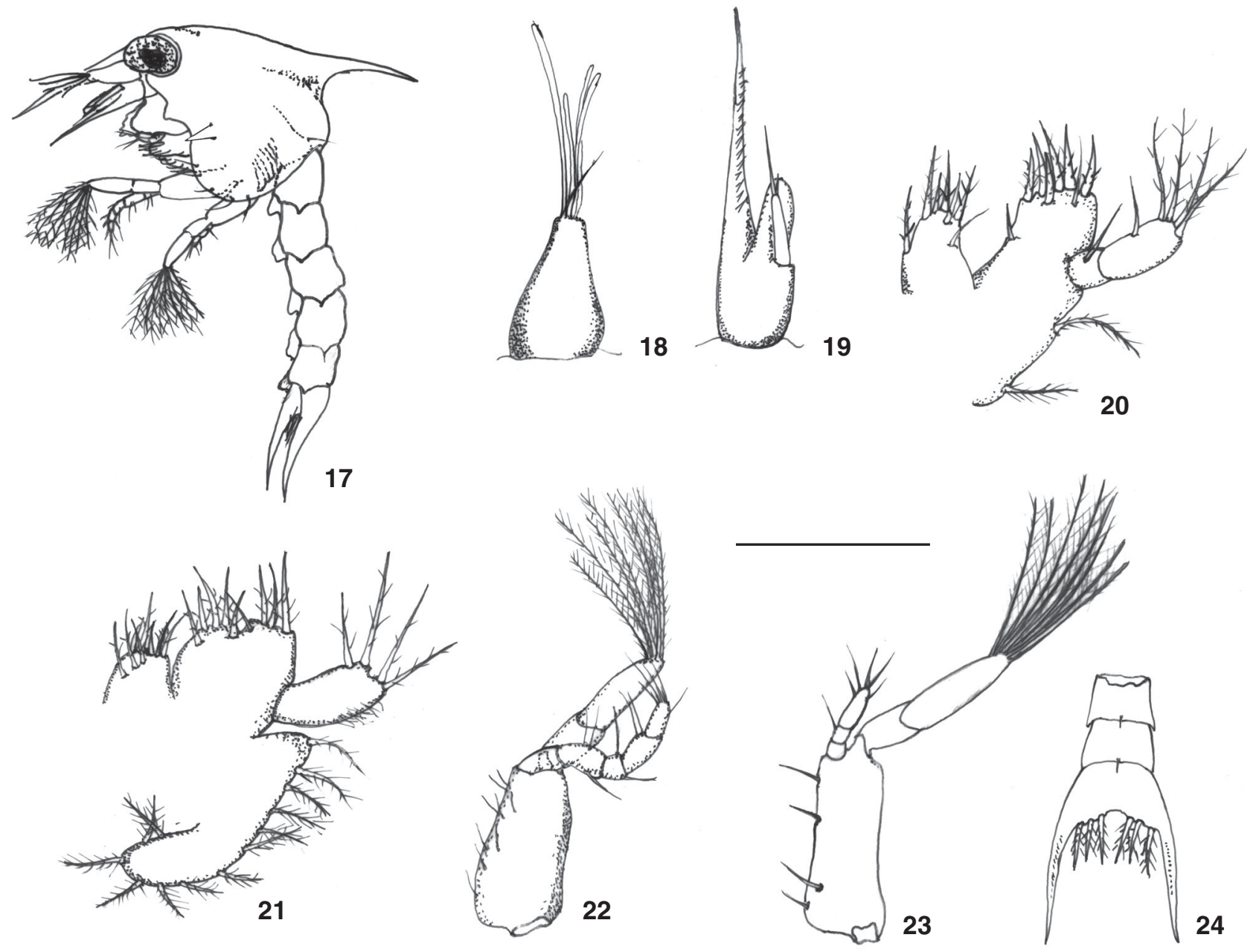

24

Figures 17-24. Armases benedicti: (17) zoea III, lateral right view; (18) antennule; (19) antenna; (20) maxillule; (21) maxilla; (22) first maxilliped; (23) second maxilliped; (24) abdomen and telson. Scale bar: $17=0.65 \mathrm{~mm}, 18=0.18 \mathrm{~mm}, 19=0.18 \mathrm{~mm}, 20=0.20 \mathrm{~mm}$, $21=0.21 \mathrm{~mm} ; 22-23=0.36 \mathrm{~mm} ; 24=0.41 \mathrm{~mm}$.

Pleopods (Fig. 25): more developed compared to previous stage, lacking setae.

\section{Megalopa}

Carapace length: $0.73 \mathrm{~mm}(0.72-0.75 \mathrm{~mm})$.

Carapace (Fig. 34): semi-rectangular with dorsal surface smooth and irregular. Posterior margin with numerous small simple setae. rostrum triangular projecting ventrally. Eyes mobiles and stalked.

Antennule (Fig. 35): peduncle 3-segmented with 0,1,1 setae, respectively. Endopod absent. Exopod 3-segmented with 0,5,4 aesthetascs, respectively, and 0,0,1 small setae.

Antenna (Fig. 36): peduncle 3-segmented having 0,1,1 setae, respectively. Flagellum 6-segmented, surpassing rostrum having 0,2,0,3,0,3 simple setae, respectively.

Maxillule (Fig. 37): endopod with three pairs of setae, as illustrated. Basal endite showing 14-16 terminal setae plumodenticulate and two simple basal setae. Coxal endite with 11 plumodenticulate. Protopod present with three long plumose setae.

Maxilla (Fig. 38): scaphognathite with 33-35 plumose setae along anterior margin and two marginal setae. Endopod unsegmented lacking setae and spines. Basal endite with proximal and distal lobes almost fused, proximal lobe with five plumose and one simple seta, distal lobe with seven plumose setae. Coxal endite with proximal and distal lobes fused having 14 setae.

First maxilliped (Fig. 39): basipod not illustrated. Endopod 2 -segmented with two simple setae. Exopod 2-segmented, proximal segment with three simple setae in the terminal portion.

Distal segment with three long and plumose setae.

Second maxilliped (Fig. 40): endopod 4-segmented with 


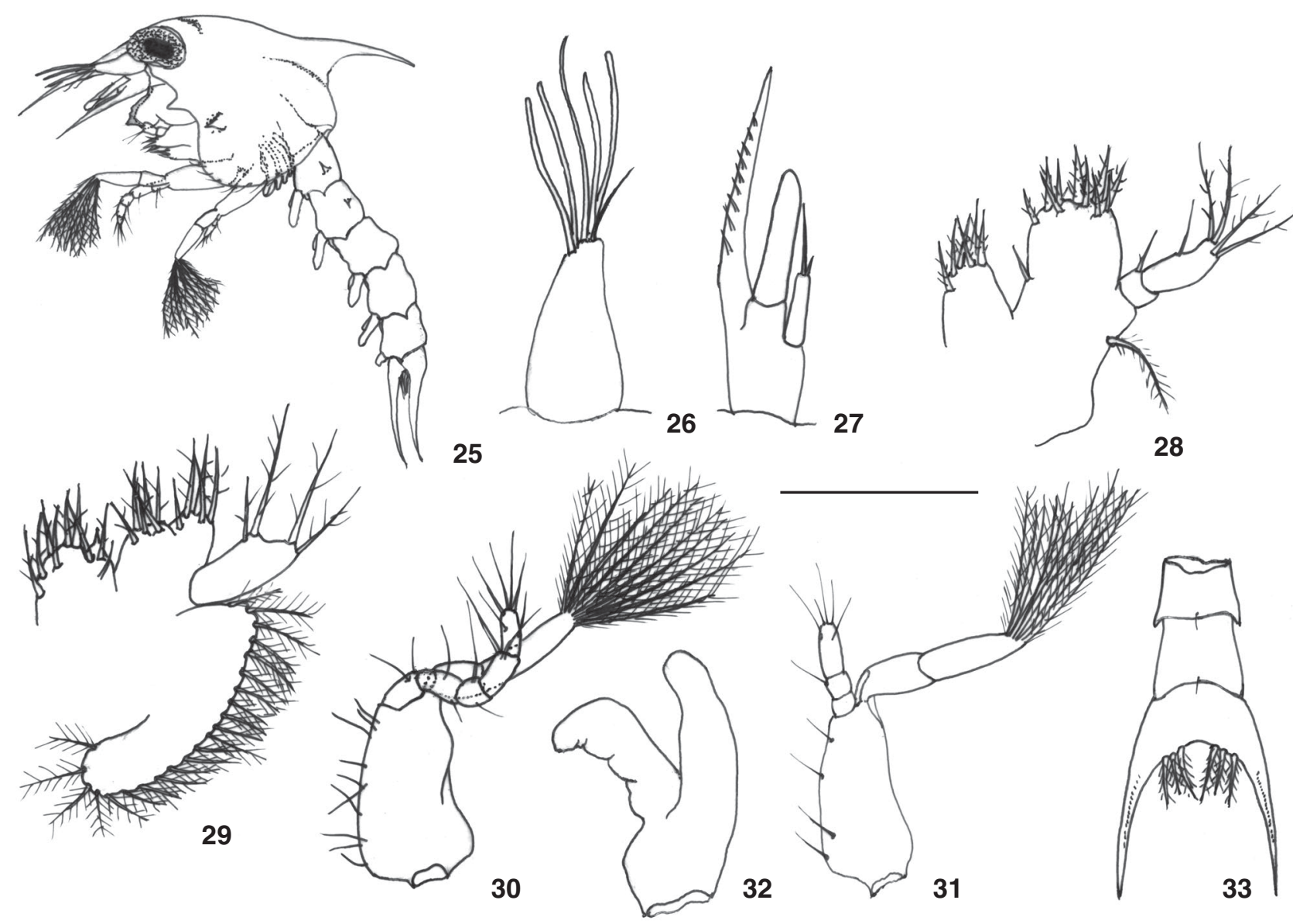

Figures 25-33. Armases benedicti: (25) zoea IV, lateral view; (26) antennule; (27) antenna; (28) maxillule; (29) maxilla; (30) first maxilliped; (31) second maxilliped; (32) third maxilliped; (33) abdomen and telson. Scale bar: $25=0.75 \mathrm{~mm}, 26=0.23 \mathrm{~mm}, 27=0.23 \mathrm{~mm}, 28=$ $0.26 \mathrm{~mm}, 29=0.27 \mathrm{~mm}, 30-31=0.44 \mathrm{~mm}, 32=0.083 \mathrm{~mm}, 33=48 \mathrm{~mm}$.

$0,1,3,6$ setae, respectively. Exopod 2-segmented, proximal segment with one small median seta, distal segment with five long plumose setae.

Third maxilliped (Fig. 41): endopod 5-segmented, with 8, 8, 4, 3, 4 setae respectively. Exopod 2-segmented, with 4-5 terminal plumose setae.

Abdomen (Figs 52-53): short than carapace showing six abdominal somites. Somite 5 with spine-like posterolateral projections. Somites 2-5 with numerous minute setae.

Pereiopods (Figs 42-46): well developed bearing numerous spaced setae. Dactyl of the fifth pereiopod with three long terminal setae and 1 small terminal spine. Other pereiopods as illustrated.

Pleopods (Figs 47-51): endopod of pleopod first to fifth setose, with 13-14, 12-14, 12-13, 11, 6-7 setae, respectively.

Telson (Fig. 53): Posterior margin convex, wider than long, completely articulated with abdomen having two pairs of small setae.

\section{DISCUSSION}

Various numbers of larval stages and different developmental durations are observed within the Sesarmidae family, ranging from two to five stages and one megalopa (IsLAm et al. 2002). However, for Armases species, including A. benedicti of the present study, the larval development is comprised of four zoeal stages before metamorphosis to the megalopal stage: $A$. angustipes (CUesta \& ANger 2001); A. cinereum (Costlow \& BookHout 1960); A. ricordi and A. rubripes (Díaz \& Ewald 1968). An exception described by CUESTA et al. (1999) occurs in A. miersii which shows an abbreviated shortened development, composed only of three larval stages. This zoeal reduction may be considered a phylogenetic advanced type of development (ANGER et al. 1995).

A morphological difference is observed in the larval stages of Sesarmidae species and $A$. benedicti. This species clearly shows a pair of small lateral spines (about $1 / 4$ of the dorsal spine size). Comparing the first zoeal stages of $A$. rubripes, $A$. ricordi and $A$. 

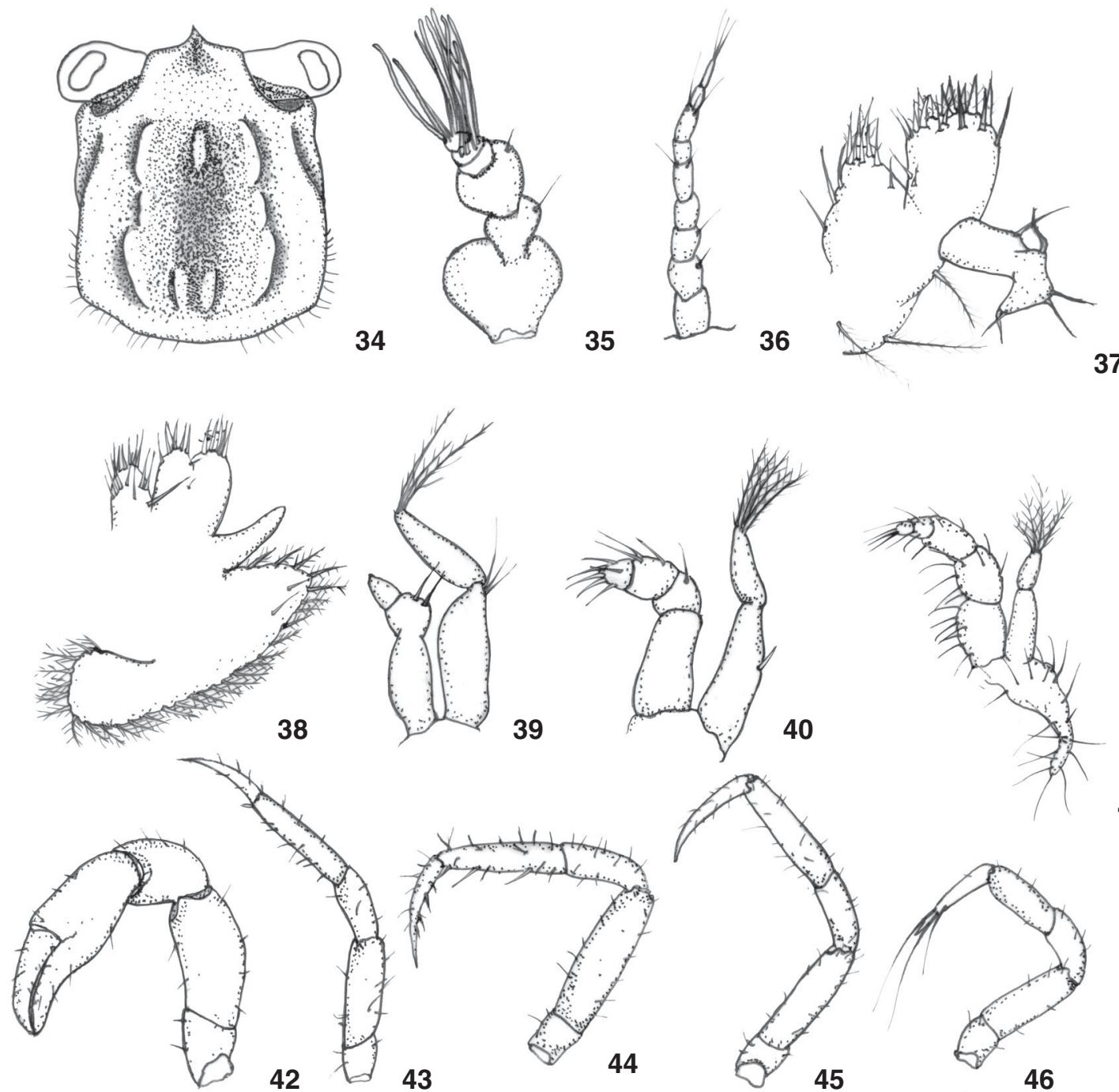

42
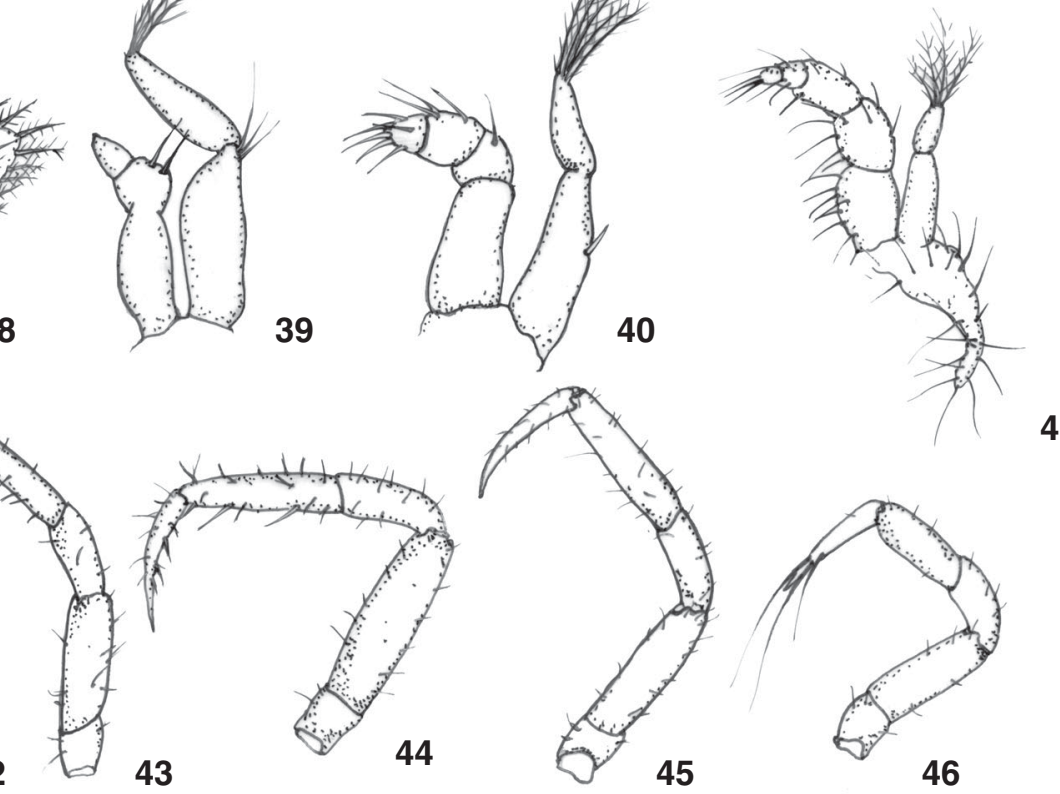

41

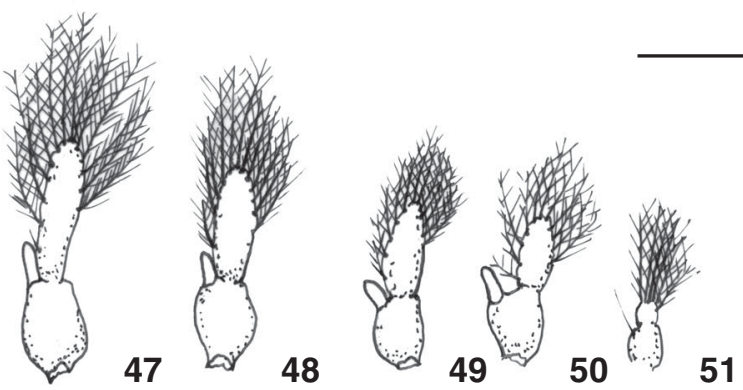

45

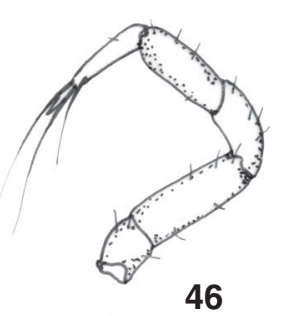

52

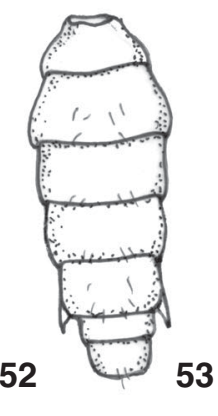

Figures 34-53. Megalopa of Armases benedicti: (34) carapace, dorsal view; (35) antennule; (36) antenna; (37) maxillule; (38) maxilla; (39) first maxilliped; (40) second maxilliped; (41) third maxilliped; (42-46) pereiopods; (47-50) pleopods; (51) uropod; (52) abdomen in straight lateral view; (53) abdomen in dorsal view. Escale bars: $34=0.50 \mathrm{~mm}, 35=0.26 \mathrm{~mm}, 36=0.24 \mathrm{~mm}, 37=0.125 \mathrm{~mm}, 38=$ $0.125 \mathrm{~mm}, 39=0.22 \mathrm{~mm}, 40=0.24 \mathrm{~mm}, 41=0.42 \mathrm{~mm}, 42-45=0.46 \mathrm{~mm}, 47-51=0.40 \mathrm{~mm}, 52-53=0.43 \mathrm{~mm}$. 
benedicti, a slight similarity can be found mainly in the zoea I, where the lateral spines are not well developed and they are shown in bud form in both species. According to Islam et al. (2002) this structure is lacking in larvae of 37 species of Sesarmidae. The absence of lateral spine was also reported for zoeae of the Parasesarma fasciatum (GUERAO et al. 2004) and Neosarmatium trispinosum (IsLam et al. 2004). However, despite the absence of lateral spines, DiAz \& EWALD (1968) observed a small protuberance in larvae of $A$. rubripes and $A$. ricordi. Such protuberance may be a remaining characteristic that is preserved in these species.

The summary of the morphological comparisions among previously described species for genus zoea I of genus Armases and present study are recorded in the table III. The zoeal setation $2+2$ (shown in the table II) of the endopod of the maxilla of $A$. benedicti is not observed in the other species described by DIAZ \& Ewald (1968) and Cuesta \& Anger (2001), in which this structure shows a pattern of $2+3$ setae. But, similar features are observed in the Sesarma species (Fransozo \& Hebling 1986, Anger et al. 1995). The number of aesthetascs and setae of the $A$. benedicti antennule are similar to $A$. rubripes, which have three aesthetascs and one simple seta, while $A$. angustipes shows three aesthetascs and two simple setae.

The subfamilies Varuninae-Sesarminae have been divided into two distinct groups according to the presence of the two lateral spines and the setation number of maxilla endopod (RicE 1980). Thus, the genera Sesarma, Aratus, Chiromantes e Armases are included in the group, which lacks lateral spines and has $(2+3)$ setae in the endopod of the maxilla. The second group is represented for the genera Hemigrapsus, Chasmagnathus, Cyclograpsus, Eriocheir e Helice that show lateral spines in the carapace and bear $2+2$ setae in the endopod of the maxilla. Following Rice (1980) proposition, A. benedicti should be included in the second group because the larvae have clearly showed (despite reduced size), lateral spines and setation 2+2 setae in the maxilla. However, Pereyra Lago (1993) suggests that more characteristics are necessary for a correct division of these sub families. In relation to our species, further filogenetic and/ or molecular studies have to be done in order to determine their correct taxonomic position, because the two distinct character may be a homoplasy or A. benedict may be placed in an erroneous family.

The megalopa of $A$. rubripes, $A$. angustipes and $A$. benedicti have shown distinguishable morphological differences. The telson of the A. rubripes megalopa described by DíAz \& EwaLD (1968) is rounded having only one distal seta but in $A$. benedicti this structure is semi-rectangular and has three small setae. However, for A. angustipes (CUESTA \& ANGER 2001), three morphological differences are found in the telson: first, lacking lateral spines and with two long terminal setae and short setae; second, supporting a pair of lateral spines and three similar pairs of setae; third, lateral spines and well developed setae. These morphological variations observed in the telson of $A$. angustipes were not found in any other species of the genus Armases.
The endopod of the maxillule in the megalopal stages of genus Armases shows 2-segmented, differing from $A$. benedicti that have only a single segment. This characteristic is similar in other species belonging to the genus Sesarma: $S$. curacaoense described by Anger et al. (1995) and S. rectum by Fransozo \& Hebling (1986) as showed in table IV. Other important differences can be found in the station of scaphognathite of maxilla in the megalopas of $A$. angustipes, A. ricordi, A. rubripes and $A$. benedicti as showed in table $\mathrm{V}$.

\section{ACKNOWLEDGMENTS}

To the Institute Millennium and to the project MADAN for the financial resource destined to this research; to the Universidade Federal do Pará and Maria I. Sampaio, Laboratory of Molecular Biology of University campus of Bragança, Pará.

\section{REFERENCES}

Abrunhosa, F.; M.A.B. Pires; J.F. Lima, \& P.A. Coelho-Filho. 2005. Larval development of Lepidophthalmus siriboia Felder \& Rodrigues, 1993 (Decapoda: Thalassinidea) from the Amazon region, reared in the laboratory. Acta Amazonica, Manaus, 35 (1): 77-84.

Anger, K; D. Schreiber \& M. Montú. 1995. Abbreviated larval development of Sesarma curacaoense (Rathbun, 1897) (Decapoda: Grapsidae) reared in the laboratory. Nauplius, Botucatú, 3: 127-154.

Bousquette, G.D. 1980. The larval development of Pinnixa longipes (Lockington, 1877) (Brachyura: Pinnotheridae), reared in the Laboratory. Biological Bulletin, Miami, 159: 592-605.

Costlow, J.D. \& C.G. Bookhout. 1960. The complete larval development of Sesarma cinereum (Bosc) reared in the laboratory. Crustaceana, Leyden, 4: 281-294.

Cuesta, J.A. \& K. Anger. 2001. Larval morphology of the sesarmid crab Armases angustipes Dana, 1852 (Decapoda, Brachyura, Grapsoidea). Journal of Crustacean Biology, Kansas, 21 (3): 821-838.

Cuesta, J.A.; M. Schuh; R. Diesel \& C.D. Shubart. 1999. Abbreviated development of Armases miersii(Grapsidae: Sesarminae), a crab that beeds in supralittoral rock pools. Journal of Crustacean Biology, Kansas, 19: 26-41.

DíAz, H. \& J.J. EwAld. 1968. A comparison of the larval development of Metasearma rubripes (Rathbun) and Sesarma ricordi H. Milne Edwalds (Brachyura, Grapsidae) Reared under similar laboratory conditions. Crustaceana, Leyden, (Suppl. 2): $225-248$.

Fransozo, A. \& N.J. Hebling. 1986. Desenvolvimento larval de Sesarma (Holometopus) rectum Randall, 1840 (Decapoda, Grapsidae), em laboratório. Revista Brasileira de Biologia, Rio de Janeiro, 46: 353-364.

Guerao, G.O.; K. Anger; U.W.E. Nettelmann \& C.D. Schubart. 2004. Complete larval and early juvenile development of

Revista Brasileira de Zoologia 23 (2): 460-470, junho 2006 
the mangrove crab Perisesarma fasciatum (Crustacea: Brachyura: Sesarmidae) from Singapore, with a larval comparison of Parasesarma and Perisesarma. Journal of Plankton Research, Oxford, 26 (12): 1389-1408.

Islam, M.S.; M. Aminur Rahman \& S. Shigemitsu. 2004. Larval development of the mangrove sesarmid crab Neosarmatium trispinosum (Brachyura: Grapsoidea) described from laboratory-reared material. Journal of Crustacean Biology, Kansas, 24 (2): 356-371.

Islam, M.S.; S. Shokita \& N. Shikatani. 2002. Larval development of the mangrove sesarmid crab Neosarmatium indicum (Brachyura: Grapsoidea) described from laboratory-reared material. Journal of Crustacean Biology, Kansas, 22: 916937.

Magalhães, C. \& N. Medeiros. 1998. The larval Development of Palaemonid shrimps from the Amazon Region reared in the Laboratory. VII. Abbreviated development of Pseudopalaemon amazonensis Ramos-Porto, 1979 (Crustacea: Decapoda: Caridea). Acta Amazônica, Manaus 28 (4): 433-448.

Marques, F. \& G. Pohle. 1996a. Laboratory-reared larval stages of Dissodactylus mellitae (Decapoda: Brachyura: Pinnotheridae) and developmental patterns within the Dissodactylus species complex. Canadian Journal of Zoology, Ottawa, 74: 47-62.

Marques, F. \& G. Pohle. 1996b. Complete Larval Development of Clypeasterophilus stebbing (Decapoda: Brachyura: Pinnotheridae) and a comparison with other species within the
Dissodactylus complex. Bulletin of Marine Science, Miami, 58 (1): 165-185.

Martin, J.W. \& G.E. Davis. 2001. An updated classification of the Recent Crustacea. Natural History Museum of Los Angeles County Science Series, Los Angeles, 39: 1-124.

Melo, G.A.S. 1996. Manual de identificação dos Brachyura (caranguejos e siris) do litoral brasileiro. São Paulo, Editora Plêiade, FAPESP, 603p.

Pereyra Lago, R. 1987. Larval development of Sesarma catenata Ortmann (Brachyura: Grapsidae: Sesarminae) reared in the laboratory. South African Journal of Zoology, Transkei, 22(3): 200-212.

Pereyra Lago, R. 1989. The larval development of the red mangrove Sesarma meinerti Ortmann (Brachyura: Grapsidae) reared in the laboratory. South African Journal of Zoology, Transkei, 24 (3): 199-211.

Pereyra Lago, R. 1993. Larval development of Sesarma guttatum A. Milne Edwards (Decapoda: Brachyura: Grapsidae) reared in the laboratory, with comments on larval generic and familial characters. Journal of Crustacean Biology, Kansas, 24 (3): 199-211.

Rice, A.L. 1980. Crab zoeal morphology and its bearing on the Classification of Brachyura. Transactions of The Zoological Society of London 35: 271-424.

Rodriguez, G. 1980. Los Crustaceos Decapodos de Venezuela. Caracas, Instituto Nacional de Invertigaciones Científicas, 494p.

Received in 14.VII.2005; accepted in 05.V.2006. 